\title{
Isolation of hydrogen generating microflora from cow dung for seeding anaerobic digester
}

\begin{abstract}
The effectiveness of using cow dung as a source for isolating hydrogen generating microflora was investigated under varying isolating conditions based on viz.: $\mathrm{pH}$ adjustment and $\mathrm{pH}$ adjustment coupled with heat treatment. The viability of the isolated microflora was tested in an anaerobic jar with respect to biogas generation, hydrogen content and $\mathrm{pH}$. The results showed that for $\mathrm{pH}$ adjusted microflora isolated from cow dung with solids content at $10 \%$ resulted in a cumulative biogas generation of 1494, 2404 and $3327 \mathrm{ml}$, whereas the corresponding cumulative hydrogen generation was found to be 424, 701 and $47 \mathrm{ml}$ during the anaerobic fermentation for $120 \mathrm{~h}$ at a $\mathrm{pH}$ of 4, 5 and 6, respectively. The biogas was free from methane when operated at $\mathrm{pH} 4$ and 5, whereas at $\mathrm{pH} 6$ methane generation was observed. In the case of microflora isolated from cow dung with $10 \%$ solids, by subjecting to $\mathrm{pH}$ adjustment coupled with heat treatment resulted in biogas free from methane content during the fermentation at $\mathrm{pH} 4,5$ and 6, respectively. At the end of $120 \mathrm{~h}$ of fermentation for a reactor $\mathrm{pH}$ at 4, 5 and 6 the cumulative biogas generation was 1685,2610 and $2353 \mathrm{ml}$, whereas the cumulative hydrogen generation was 509, 1198 and $1165 \mathrm{ml}$, respectively. A maximum of $41 \%$ and $62 \%$ hydrogen was obtained at $\mathrm{pH} 5$ for microflora isolated based on $\mathrm{pH}$ adjustment and $\mathrm{pH}$ adjustment coupled with heat treatment. The effect of initial solids content of the cow dung on the isolating efficiency of hydrogen generating microflora was also investigated at $\mathrm{pH} 5$ and 6 coupled with heat treatment. The results revealed that with the increase in initial solids content of the cow dung the optimum heat treatment period also increased as the $\mathrm{pH}$ increased from 5 to 6.
\end{abstract}

Keyword: Biohydrogen, Anaerobic digestion, Cow dung, Isolation, Hydrogen generating microflora 